\title{
The traditional clothing industry of Banjarmasin Sasirangan: A portrait of a local business becoming an industry
}

\author{
Jumriani*, Syaharuddin, Ersis Warmansyah Abbas, Mutiani and Muhammad Rezky Noor Handy \\ Lambung Mangkurat University, Banjarmasin, Indonesia \\ *Correspondence email: jumriani@ulm.ac.id
}

\section{ARTICLE INFO}

- Research Article

Article History

Received 5 September 2020

Accepted 11 October 2021

Published 28 October 2021

\section{Keywords}

ethnic culture; industry; local fabric; Sasirangan

JEL Classification

J24; M31; 014

\begin{abstract}
Sasirangan is a traditional fabric typical of the Banjar tribal community and has now been developed into an industrial product in Banjarmasin. Sasirangan's business development shows a significant development and it becomes very essential to pay attention to how to maintain its business. This article aims to describe the business operations and distribution patterns in the Sasirangan clothing industry. The qualitative approach was used in this study coupled with data collection through interviews, observations, and documentation. The results showed that Sasirangan fabric products are produced by artisans who work individually or in groups and marketed by traders. Marketing of Sasirangan cloth products uses a direct distribution pattern to consumers, and indirectly uses a merchant intermediary who then resell them to consumers. The collaboration of Sasirangan artisan and traders can be further enhanced to develop a convection industry based on local culture. The findings of this study provide a further description of how local culture-based businesses require support from the government and other parties to maintain business sustainability.
\end{abstract}

To cite this article: Jumriani, Syaharuddin, Abbas, E. W., Mutiani, \& Handy, M. R. N. (2021). The traditional clothing industry of Banjarmasin Sasirangan: A portrait of a local business becoming an industry. Journal of Socioeconomics and Development, 4(2), 236-244. https://doi.org/10.31328/jsed.v4i2.1579

ISSN 2615-6075 online; ISSN 2615-6946 print

(c)UWG Press, 2021

\section{INTRODUCTION}

Culture-based industries compete in the economic field by involving various elements of business actors. The line of business of the culture-based industry can be traditional fabric, local food, local drinks, and other aspects of regional culture. A culture-based industry is an industry that functions as the mainstay of a region's economy by developing local culture and increasing economic growth (Akhir et al., 2018). Industrial products based on local potential have long been carried out by various countries, including the Miao people in China. Chinese local culture has become a source of rural economic development involving various elements, strategies, and cooperation (hen et al., 2021). So, as in Malaysia, for example, the traditional fabric-based industry has made a significant contribution to the community's economy. Traditional fabric industry is the second highest industry in Malaysia, influencing imported commodities and labor (Ismail et al., 2019; Akhir et al., 2017).

In Indonesia, the highly potential local traditional fabrics has been developed as an industrial product. Traditional cloth is an art and culture that is found in numerous regions in Indonesia. This product is created by the skill of human hands using a loom. This ancestral heritage is an asset that must be preserved and developed as a feature of the nation's culture. Traditional fabrics are fabrics associated with local 
culture, produced traditionally and for the benefit of certain customs. However, nowadays, various traditional fabrics have been developed into the community's economic activities. The production of traditional fabrics is not only for cultural purposes but also for industrial purposes with economic value. Batik, a type of traditional cloth in Indonesia, has now been developed into an industrial product. For example, Tuban batik cloth which was initially only produced to show social status, group identity, rituals, and life philosophy, turns into an item created dynamically into various industrial products in the form of clothing, accessories, and various other creations (Kristianto et al., 2021; Ciptandi et al., 2018).

The development of traditional fabrics into industrial products has expanded the dimensions of meaning, principles, and goals of traditional fabric production (Sunarya, 2018; Sunarya \& Anas, 2014). Sasirangan fabric has been used to create various products such as clothes, bags, shoes, sandals, and accessories (Jumriani et al., 2019; Prasetiyo et al., 2016).

One of the traditional fabric products in Indonesia that evolves in the industrial economy is Sasirangan. Sasirangan is a traditional fabric from Banjarmasin, South Kalimantan Province. This traditional cloth was originally related to the community's belief for healing the sick (Redho, 2016). According to the data from the Department of Industry and Trade of the City of Banjarmasin, Sasirangan fabric occupies the first rank of industrial commodity, with an average investment value of 26 million rupiahs and value production of 11,934 million rupiahs per year. Based on these data, it can be said that in the field of industry, Sasirangan fabric has the potential to support the industrial activities in the city of Banjarmasin. This development cannot be separated from the distribution pattern carried out by the involved parties. The sustainability of economic activity focuses not only on production and innovations made to suit consumer needs, but also on how the products can reach consumers (Krisdayanti et al., 2020; Nabay et al., 2020; Смерічевський et al., 2018). Therefore, distribution has an essential role in economic activity. It is focused on selling products and includes activities to distribute goods produced according to consumer demand (Philip Kotler; Gary Armstrong; Yati Sumiharti, 1999; Rachman \& Yuningsih, 2010). Distribution activities are also a means to connect with community needs.
Sasirangan fabric industry is originated in Sasirangan Village. Sasirangan Village refers to Seberang Mesjid Village, Banjarmasin City because the people of this village develop Small and Medium Enterprises (SMEs) devoted to the Sasirangan fabric. In 2019, this village had 13 business units producing Sasirangan products. To face challenges and market competition, SMEs must be able to survive by determining patterns and strategies that can support their economic activities. SMEs that rely on local products must implement various steps to increase marketing and product sales according to consumer behavior and needs.

The production and distribution process of Sasirangan fabric involves a number of actors and their derivative industries and requires the support of other parties to ensure business continuity. This article aims to describe business operations and distribution patterns in the Sasirangan fabric clothing industry in Sasirangan Village, Banjarmasin.

\section{RESEARCH METHOD}

The research was conducted in Sasirangan Village, which is located at Seberang Masjid Village, Banjarmasin. This study used a qualitative approach in which data collection was done by interview and direct observation to respondents. The interview was carried out openly and interviewees answered the questions freely. The results of the interview recordings were then written into a word-for-word transcript. To obtain valid data, the results of interviews were cross-checked with the other respondents.

In the process, researchers were involved in every stage of the economic activity of Sasirangan fabric, especially in production and distribution activities. The stages started from production, packaging, to distribution to the consumers' hands. Observations were employed at several production sites for Sasirangan fabrics, ranging from individual businesses to Sasirangan fabric industry, which was incorporated in one business group. The observations aimed to identify the production and distribution pattern. To ensure the validity of the research data, the results of the interviews were also cross-checked with the results of observations and documentation, in which the secondary data were obtained from several literature studies and information relevant to the research. 
The data analysis technique followed the pattern of Miles and Huberman, consisting of data reduction, data presentation, and verification (King et al., 2018; Sugiyono, 2013). First, the data analysis process was done by selecting data relevant to the research focus. Then, the data were presented in a narrative form to get a conclusion from the data obtained. In analyzing the data until the verification stage, the researcher also continued to test the validity of the data. Referring to the opinion of Creswell (Creswell \& Poth, 2016), several steps can be taken to obtain the validity of the data. In this study, researchers used extended observations and triangulation of sources, techniques, and time to test the validity of the data obtained in research activities

\section{RESULT AND DISCUSSION}

\section{Products of Sasirangan}

The results of observations showed the conditions of the production and distribution process, and the activities that shaped the social interaction of industrial actors in Sasirangan Village. The primary data of research were the registration documents of industrial business actors in Sasirangan Village obtained from the Seberang Mosque Village Office, Banjarmasin, Indonesia. The research interviewed respondents of several owners of Sasirangan fabric business and the artisans (Table 1 ).

Sasirangan was initially a cloth related to the people's belief about its usefulness for healing the sick. Sasirangan cloth has various motifs (Table 2). Each motif has a certain meaning, so Sasirangan is also referred to as the Pamintan cloth, which means cloth of demand. Thus, Sasirangan cloth was originally made only to fulfill the requests of people in need.

Table 1. Demographics of Respondents Working on Sasirangan Product

\begin{tabular}{ccccc}
\hline No & Name & Age & Education & Expertise \\
\hline & & Years & & \\
1 & HL & 32 & Junior high school & Painting \\
2 & ST & 40 & Primary school & Baste \\
3 & RJ & 28 & Senior High School & Painting \\
4 & MS & 35 & Junior high school & Baste \\
5 & MN & 50 & Primary school & Baste \\
6 & RD & 25 & Junior high school & Coloring \\
7 & RN & 36 & Junior high school & Coloring \\
8 & ML & 50 & Senior High School & Owner \\
9 & IR & 48 & Senior High School & Owner \\
10 & SS & 45 & Senior High School & Owner \\
\hline
\end{tabular}

Sasirangan motifs can be classified into three types. First, the stripe motif, which is arranged lengthwise with specific characteristics such as perpendicular lines and curved lines. Second, the fried rice motif, which is a motif that usually stands alone without any decoration on the central motif. Third, the variation motif, which is a decorative motif to beautify the appearance. This motif usually involves the addition of images around the central motif.

Table 2. Sasirangan Motifs

\begin{tabular}{ll}
\hline & Traditional Motif \\
\hline - Gigi Haruan & - Tampuk Manggis \\
- Gagatas & - Gagatas \\
- Kangkung Kaombakan & - Mayang Maurai \\
- Iris Pudak & - Gelombang \\
- Ular Lidi & - Bintang \\
- Tampuk Manggis & - Hiris Pudak \\
- Kulat Karikit & - Kembang Sakaki \\
- Daun Jaruju & - Ombak Sinapur Karang \\
- Kembang Kacang & - Naga Balimbur \\
- Bayam Raja & - Bintang \\
- Ramak Sahang & - Jajumputan \\
- Daun Katu & \\
& Modern Motif \\
- Gradasi & - Ketupat \\
- Langsat & - Abstrak \\
- Sarigading & - Rainbow \\
- Naga & - Batung Batulis \\
- Laba-laba & - Musik Panting \\
- Galuh Manginang & - Kupu-Kupu \\
- Bakantan & - Mandulang Intan \\
- Pasar Terapung & \\
\hline
\end{tabular}

Initially called pamintan cloth solely for medicinal purposes, Sasirangan is now used as a material for making clothes. Even, Sasirangan is produced with various variations and nuances. Along the way, Sasirangan fabric is produced not only to meet the demand for medical care but also to be a part of a community economic activity.

The origin of the word Sasirangan is "Sirang", a verb adopted from the process of manufacturing the cloth, which is "Menyirang". Another characteristic of Sasirangan fabric that makes it different from Batik is the production stage, which is done by drawing patterns manually on a piece of cloth. The pattern is then sewn using the basting technique. "Menjelujur" is an activity carried out by Sasirangan fabric artisan by sewing a pattern that has been painted on a piece of cloth (Figure 1 and 2). Fabrics that have been sewn with the basting technique will be wrinkled and then colored. The results of basting and coloring will form the desired pattern according to the pattern of the Sasirangan fabric (Figure 3). 

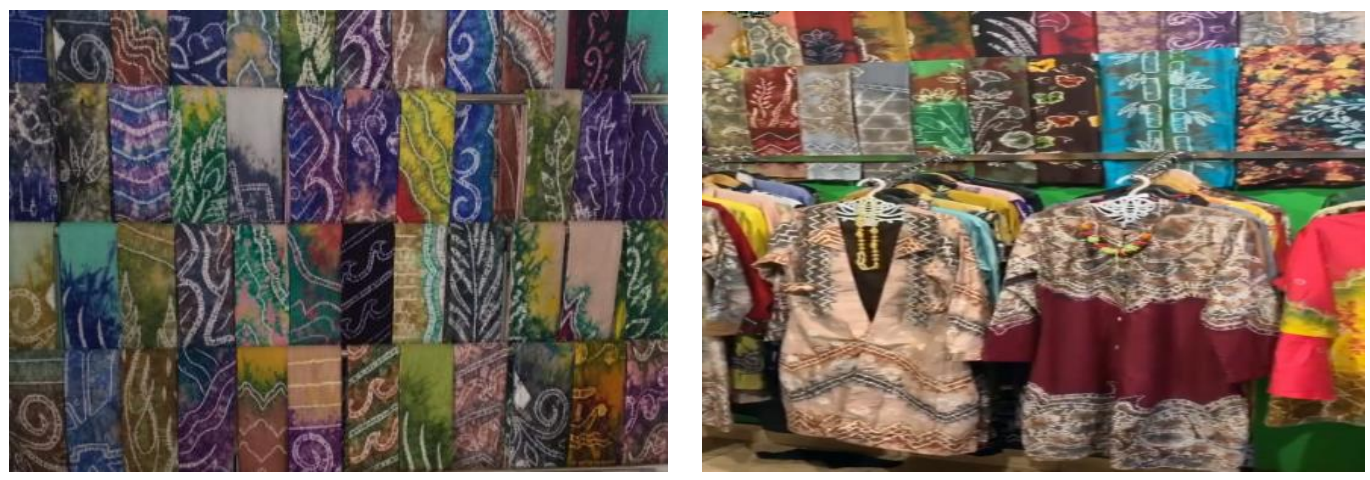

Figure 1. Patterns and product Sasirangan fabric
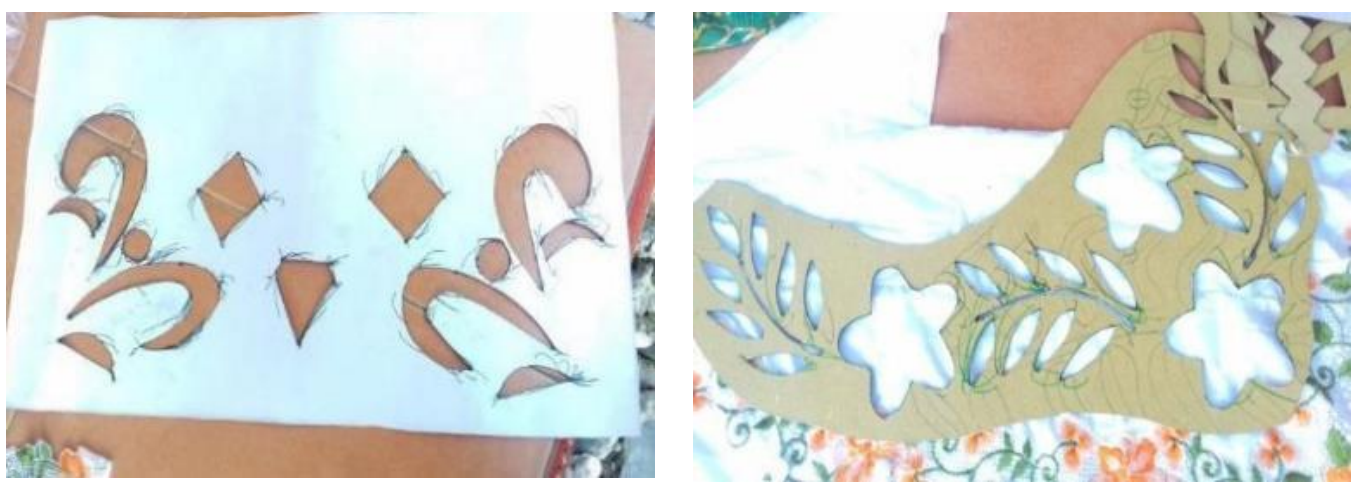

Figure 2. Sasirangan fabric patterns

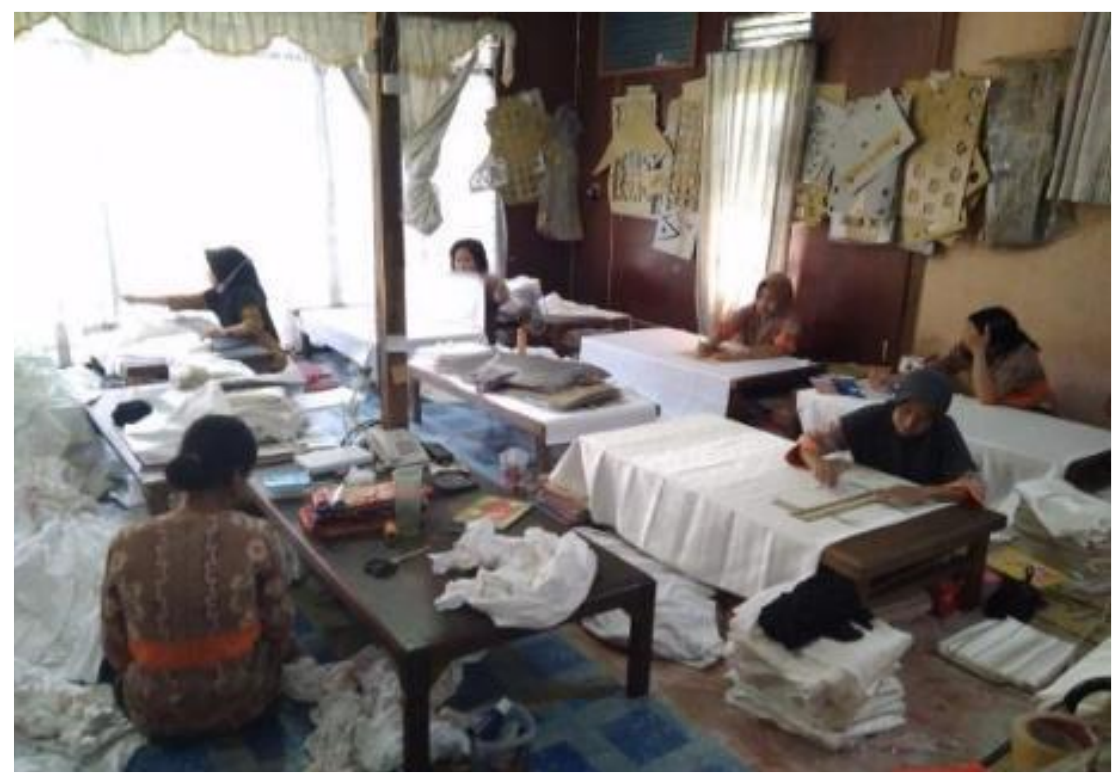

Figure 3. The activity of artisan drawing Sasirangan fabric patterns 
Table 2 shows various motifs of Sasirangan fabric, displayed in the names of local motifs. These motifs have their own particular meaning, a certain symbol, message, or hope to be delivered from the pattern of Sasirangan. Research by Ramli et al. (2017) showed the motif of a traditional cloth representing images or symbols of plants and the surrounding environment. Traditional fabrics also have various aesthetic values and the meaning of each pattern created (Vivithkeyoonvong et al., 2021; Akhir et al., 2017). Likewise, Sasirangan fabric motifs have been developed and modified without leaving the characteristics of the original ones (Jumriani et al., 2019; Redho, 2016).

Production activities of Sasirangan fabric still use traditional technology, equipment, and methods. The various stages in the production of Sasirangan fabric are carried out traditionally, with simple equipment and by utilizing human labor manually, such as in the stage of painting Sasirangan motifs.

Sasirangan Village can be part of the One Village One Product (OVOP) program developed by the Ministry of Industry of the Republic of Indonesia. This is one of the approaches to increase the potential of featured products with the characteristics of the local area. In other words, OVOP is a program that utilizes the products of community culture (Jumriani et al., 2019). Sasirangan fabric was initially a local product as a regional specialty, but now it has economic value as it goes through production and distribution. Thus, this activity can maintain one of the cultural aspects of South Kalimantan while using it as a product that can provide economic benefits. There are two advantages to developing OVOP, i.e. it can increase people's income as business actors, and it can increase the community's sense of pride and confidence in local products with an added value.

An industrial area or village pays attention to several aspects such as local workers, worker positions, transportation, marketing places, and other services that can support business continuity. The development of a village is influenced by physical and non-physical aspects. The physical aspect here is closely related to the structure of the location and the position of the location, while the non-physical aspects include the availability of facilities, infrastructure, and marketing. The relationship between individuals plays an essential role in how a village develops (Philip Kotler; Gary Armstrong; Yati Sumiharti, 1999; Tamaya et al., 2013). Developing Sasirangan fabric industry is to accelerate industrial growth, provide convenience for industrial activities, encourage industrial activities, and provide local industrial facilities that are environmentally sound (Johnson et al., 2019; Sunarya, 2018). Furthermore, Sasirangan Village is expected to have a pattern of community economic empowerment that aims to develop the community's economic potential in an area and support local economic activities in the region.

\section{Business Activity}

Industrial business people in Sasirangan Village play an essential role in maintaining the sustainability of industrial activities. One of them is the role in carrying out distribution activities so that their products can reach consumers. Distribution is defined as a process of delivering a commodity from producer to consumer with a series of distribution patterns. The distribution pattern is a series of interdependent organizations involved in making a commodity ready for use or consumption (Syaharuddin et al., 2020; Tamaya et al., 2013).

Industrial business actors in Sasirangan Village include artisans and traders. Skills and business capital are significant for business actors in Sasirangan Village. The role of artisans is carried out by those who have skills in producing Sasirangan fabric. Meanwhile, the traders do not have the skills but contribute the capital in trading activities for Sasirangan fabric. The artisans in Sasirangan Village who work in groups join either one of the 2 (two) groups known as Kelompok Usaha Bersama (KUBE/ Joint Business Group), namely KUBE Kenanga and KUBE Orchid. Each group consists of 6 artisans. They have expertise in every stage of making Sasirangan fabric. The main focus of the expertise of Sasirangan fabric lies in their ability to draw patterns of traditional motifs. The expertise of Sasirangan fabric artisans can also be seen in their ability to perform the technique known as attacking by basting in making the product. Tracing is the activity of sewing lines that have carefully been patterned as it is not exposed to the dye.

The difference between independent artisans and those joining group management lies in the source of capital. For the artisans who work independently, the business capital comes from personal funds. Meanwhile, for artisans who join group management, the source of capital is obtained from the loan of the 
social service of the KUBE, which was formed in 2006. Initially, the assistance was in the form of tools and materials. The next assistance was in the form of funds for business capital. In 2008, capital assistance was provided up to ten million rupiahs per person.

\section{Distribution Pattern}

Distribution activities involve all parties in economic activity to create and retain customers. On this basis, distribution activities play an essential role in helping a business actor achieve his goals (Ellram \& Ueltschy Murfield, 2019; Hao et al., 2018; Johnson et al., 2019; Katz-Gerro \& Sintas, 2019). The distribution pattern of Sasirangan cloth products in Sasirangan Village is closely related to how artisans and traders collaborate in Sasirangan Village (Figure 4).

(a) Direct

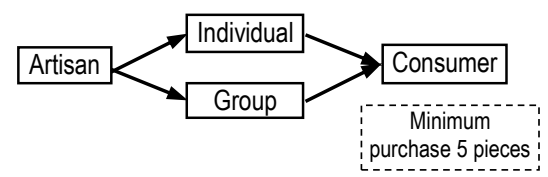

(b) Indirect

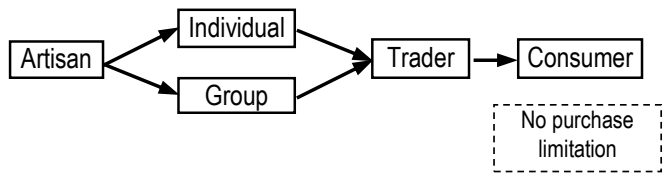

Figure 4. Distribution pattern of Sasirangan fabric

The artisans, either individually or in groups, market their products directly to consumers, as presented in Figure 4(a). Consumers can directly buy Sasirangan products from artisans with a minimum purchase of 5 (five) pieces of Sasirangan fabric.

Meanwhile, the artisans, either individually or in groups, also market their products through traders, who then sell them to consumers, as seen on Figure 4(b). Through traders, consumers can buy Sasirangan fabric products at retail price without any minimum purchase amount.

From the two distribution patterns, it can be said that the continuity of distribution activities in Sasirangan Village cannot be separated from the cooperation between traders and artisans in Sasirangan Village. The partnership is built due to the limitations of traders in carrying out production so that they can participate in selling Sasirangan fabric in Sasirangan Village. A collaboration was welcomed by artisans who both work in groups (KUBE) or independently.

The existence of the cooperation generates a significant advantage to both artisan and traders. The artisans can still distribute their products through merchant shops, while traders can still participate in selling Sasirangan fabrics in Sasirangan Village even though they do not have the expertise in doing production. The relationship that occurs between the artisan and the trader is a collaboration between two parties to exchange benefits and achieve common goals (Kristiningtyas, 2012). In the distribution pattern, a mechanism is used as a connecting system for a product to consumers. In general, the purpose of distribution activities is to satisfy consumers by offering goods and services related to pricing and promotion to achieve the expected goals (Harjanti et al., 2015; Ismono \& Restiana, 2011). The distribution system contains the order of ways that must be taken to distribute goods and services to consumers. For the distribution process to run smoothly, distributors must pay attention to various conditions from the producer and consumer sides (Abbas et al., 2019; Abbas \& Rajiani, 2017; Bačík et al., 2019; Rajiani \& Abbas, 2019; Ramli et al., 2017).

\section{Research Implication}

An economic activity contains essential elements that support production and distribution activities. This study found that the effectiveness of traditional fabric-based clothing industry is closely related to the role of the artisans. Their ability to innovate the product will affect the amount of demand for a Sasirangan fabric product. According to research results by Indarti et al. (2020), innovation in Malaysia's traditional fabric industry affects industrial companies' performance. Evolution in the traditional fabric industry will bring various innovations in terms of production processes to distribution methods. The results of empirical analysis on traditional fabric research in Malaysia also showed that only product innovation has a significant effect on company performance (Akhir et al., 2018; Ramli et al., 2017). Therefore, it can be said that the number of requests from consumers strongly influences the size of the distribution of Sasirangan fabric. Sasirangan fabric product innovation in terms of motifs and product creations determines the number of requests.

In China, local products can develop into an industry that supports the community's economy. This 
requires a strong integration not only in the production system but also the distribution channels with the principle of cooperation. The mechanism is also characterized by a framework that allows all elements to be involved, such as the community, government, and various policies (Chen et al., 2021). In this regard, in the Sasirangan fabric industry, the distribution pattern illustrated the cooperation between Sasirangan artisans and traders. In general, artisans were able to produce the fabric but they showed a lack of capital in their business. Therefore, they marketed their products to traders to be distributed to consumers. There should be a neat arrangement between artisans and traders in a local product distribution system of a traditional clothing business. The role of the Banjarmasin City government is essentially needed in regulating the Sasirangan business. It is suggested that the government issues a regulation system in terms of investment incentives, workers training, promotion, and infrastructure improvement.

\section{CONCLUSION AND SUGGESTION}

The Sasirangan fabric industry in the city of Banjarmasin is able to transform traditional fabric products to be a part of the community's economic activities. The success of the industry is highly dependent on the role of economic actors in carrying out economic activities. The expertise of artisans in producing Sasirangan products is supported by the involvement of traders who give funding contribution to market products to consumers. The pattern of distribution of Sasirangan fabric products takes place in collaboration between artisan and traders. The distribution pattern occurs directly by the artisan who sells their products to consumers. Meanwhile, the indirect distribution pattern is carried out through intermediary traders who resell Sasirangan products to stores or individually to consumers.

The collaboration between artisan and traders is essential to maintain and develop innovations in terms of production and distribution of Sasirangan fabric products to a wider market area. This collaboration can be a model to maintain and improve the sustainability of local production industries as superior products of regional identity and developed into industrial economies of scale.

The traditional clothing industry of Sasirangan fabric serves as a means to maintain the existence of local culture. The sustainability of the Sasirangan fabric business requires the role of the government to support and regulate the business to become more developed. It is recommended for the government to issue policies in terms of investment incentives, worker training, promotion, and infrastructure improvement. The skills of artisans for Sasirangan fabric products should be improved to innovate, develop motifs and product creations according to the needs and trends that consumers are interested in.

\section{REFERENCES}

Abbas, E. W., Hadi, S., \& Rajiani, I. (2019). "Guru Sekumpul" as the prophetical model of entrepreneurship education from islamic perspective. Proceedings of ADVED. Retrieved from https://www.ocerints.org/adved19_epublication/papers/69.pdf

Abbas, E. W., \& Rajiani, I. (2017). A new creative model of da'wah as a medium of economic development in Indonesia. Economic and Social Development: 20th International Scientific Conference "Economic and Social Development" Prague, 27-28 April 2017. Book of Proceedings, 302-306.

Akhir, N. H. M., Ismail, N. W., Kaliappan, S. R., \& Said, R. (2017). Intersectoral linkages of Malaysian Batik Industry: An application of input- output analysis. Jurnal Ekonomi Malaysia, 51(1), 57-68. https://doi.org/10.17576/JEM-2017-5101-5

Akhir, N. H. M., Ismail, N. W., \& Utit, C. (2018). Malaysian batik industry contribution analysis using direct and indirect effects of input-output techniques. International Journal of Business and Society, 19(1), 181-194. Retrieved from http://www.ijbs.unimas.my/images/repository/pdf /Vol19-no1-paper12.pdf

Bačík, R., Fedorko, R., Abbas, E. W., Rigelský, M., Ivanková, V., \& Obšatníková, K. (2019). The impact of selected quality management attributes on the profitability of top hotels in the Visegrad Group countries. Polish Journal of Management Studies, 19(1), 46-58. https://doi.org/10.17512/pjms.2019.19.1.04

Chen, Z., Ren, X., \& Zhang, Z. (2021). Cultural heritage as rural economic development: Batik production amongst China's Miao population. Journal of Rural Studies, 81, 182-193. https://doi.org/10.1016/j.jrurstud.2020.10.024

Ciptandi, F., Sachari, A., Haldani, A., \& Sunarya, Y. Y. (2018). Identity shift on traditional clothes for women Tuban, East Java, Indonesia. Proceedings 
of the 4th Bandung Creative Movement International Conference on Creative Industries 2017, 252-256. https://doi.org/10.2991/bcm17.2018 .48

Creswell, J. W., \& Poth, C. N. (2016). Qualitative Inquiry and Research Design: Choosing Among Five Approaches. SAGE Publications. https://books.google.co.id/books?id=Ykruxor10cY C

Ellram, L. M., \& Ueltschy Murfield, M. L. (2019). Supply chain management in industrial marketingRelationships matter. Industrial Marketing Management, 79, 36-45. https://doi.org/10.1016/j.indmarman.2019.03.007

Hao, F., Wang, S., Feng, Z., Yu, T., \& Ma, L. (2018). Spatial pattern and its industrial distribution of commercial space in Changchun based on POI data. Geographical Research, 37(2), 366-378. Retrieved

from http://www.dlyj.ac.cn/EN/10.11821/dlyj20180201 0

Harjanti, I. M., Astuti, K. D., \& Yesiana, R. (2015). Pola distribusi komoditas pertanian unggulan di Desa Mlatiharjo Kecamatan Gajah Kabupaten Demak. 161-176. Retrieved from http://ejournal2.undip.ac.id/index.php/jpk/pages/ view/Conferences

Indarti, Rahayu, I. A. T., \& Peng, L. H. (2020). Sustainable batik production: Review and Research Framework. 66-72. https://doi.org/10.2991/icracos-19.2020.14

Ismail, N. W., Akhir, N. H. M., Kaliappan, S. R., \& Said, R. (2019). The impact of innovation on firm performance in the Malaysian batik industry. International Journal of Business and Globalisation, 23(1), 1-25. https://doi.org/10.1504/IJBG.2019.100784

Ismono, R. H., \& Restiana, R. (2011). Distribution pattern and corn marketing efficiency in South Lampung Regency. Jurnal Ilmiah ESAI, 5(1), 2029. https://doi.org/10.25181/esai.v5i1.1032

Johnson, J. S., Matthes, J. M., \& Friend, S. B. (2019). Interfacing and customer-facing: Sales and marketing selling centers. Industrial Marketing Management, 77, 41-56. https://doi.org/10.1016/j.indmarman.2017.08.011

Jumriani, J., Subiyakto, B., \& Syaharuddin, S. (2019). Social interaction sasirangan traders village in The City of Banjarmasin as a Learning Resources on Social Studies. The Innovation of Social Studies Journal, 1(1), 65-77. https://doi.org/10.20527/iis.v1i1.1369
Katz-Gerro, T., \& Sintas, J. L. (2019). Mapping circular economy activities in the European Union: Patterns of implementation and their correlates in small and medium-sized enterprises. Business Strategy and the Environment, 28(4), 485-496. https://doi.org/10.1002/bse.2259

King, N., Horrocks, C., \& Brooks, J. (2018). Interviews in Qualitative Research. SAGE. https://books.google.co.id/books?id=iOsnITKC48 $\mathrm{gC}$

Kristianto, A. H., Widya, P. R., \& Nadapdap, J. P. (2021). The portrait of the underground economy and tax evasion: Descriptive analysis from border region. Journal of Socioeconomics and Development, 4(2), 156-165. https://doi.org/10.31328/jsed.v4i2.2211

Krisdayanti, M., Subiyakto, B., \& Mutiani, M. (2020). Portrait of marketing activities in banjar raya fish auction. The Kalimantan Social Studies Journal, $1(2)$, 184-190. https://doi.org/10.20527/kss.v1i2.2041

Kristiningtyas, W. (2012). Eksistensi pasar tradisional ditinjau dari konsep geografi, interaksi sosial dan perilaku produsen-konsumen. Journal of Educational Social Studies, 1(2), 138-145. Retrieved from https://journal.unnes.ac.id/sju/index.php/jess/arti cle/view/745

Nabay, O., Koroma, M., Johnson, A. J., \& Kassoh, F. S. (2020). Analysis of the profitability and marketing distribution channels of sweet potato business in Sierra Leone. Journal of Agricultural Extension and Rural Development, 12(2), 26-35. https://doi.org/10.5897/JAERD2019.1123

Philip Kotler; Gary Armstrong; Yati Sumiharti, S. E. I. N. (1999). Prinsip-prinsip Pemasaran, Jilid 1 (Jakarta). Erlangga. Retrieved from //repository.unsimar.ac.id/index.php?p=show_det ail\&id=143\&keywords=

Prasetiyo, D., Arisanty, D., \& Nugroho, A. R. (2016). Upaya pengrajin sasirangan di Kampung Sasirangan Banjarmasin dalam menjaga keberlangsungan industri. Jurnal Pendidikan Geografi, 1(2), 19-27 https://doi.org/10.20527/jpg.v1i2.1402

Rachman, G. G., \& Yuningsih, K. (2010). Pengaruh biaya distribusi dan saluran distribusi terhadap volume penjualan (Studi pada Sari Intan Manunggal Knitting Bandung). Jurnal Riset Akuntansi dan Bisnis, 10(2), 151-175. https://doi.org/10.30596/jrab.v10i2.473 
Rajiani, I., \& Abbas, E. W. (2019). The value in Banjarese culture through the thought of a prominent ulema as a model of developing entrepreneurship based religion. Proceedings of the 33rd International Business Information Management Association Conference, IBIMA 2019: 10-11 April 2019, Granada, Spain. Retrieved from https://ibima.org/accepted-paper/the-value-inbanjarese-culture-through-the-thought-of-aprominent-ulema-as-a-model-of-developingentrepreneurship-based-religion/

Ramli, S., Rani, M. K. A. A., \& Zamari, Z. M. (2017). Exploration of batik lukis motifs as a medium of art communication in Pahang. Jurnal Komunikasi: Malaysian Journal of Communication, 33(1), Article $1 . \quad$ Retrieved from https://ejournal.ukm.my/mjc/article/view/17160

Redho, M. (2016). Mengenal Kain Tradisional Kalimantan Selatan dan Cara Mudah Membuat Kain Sasirangan Warna Alam. Sibuku Media.

Sugiyono. (2013). Memahami Penelitian Kualitatif (Cetakan Ke 8). Bandung, Alfabeta. 234p

Sunarya, Y. Y. (2018). Adaptasi unsur estetik sunda pada wujud ragam hias batik Sunda. Journal of Visual Art and Design, 10(1), 27-51. https://doi.org/10.5614/j.vad.2018.10.1.3

Sunarya, Y. Y., \& Anas, B. (2014). The priangan batik in the constellation of modern aesthetics. Journal of Visual Art and Design, 6(1), 9-16. https://doi.org/10.5614/itbj.vad.2014.6.1.2

Syaharuddin, S., Susanto, H., \& Putra, M. A. H. (2020). Portrait of community economic activities in the river as a learning resources on social studies with local culture-based. The Innovation of Social Studies Journal, 1(2), 178-187. https://doi.org/10.20527/iis.v1i2.2095

Tamaya, V., Sulandari, S., \& Lituhayu, D. (2013). Optimalisasi kampung batik dalam mengembangkan industri batik Semarang Di Kota Semarang. Journal of Public Policy and Management Review, 2(1), 151-160. https://doi.org/10.14710/jppmr.v2i1.1612

Vivithkeyoonvong, S., Chairunnisa, S., Onngernthayakorn, K., \& Sathapatyanon, J. (2021). Consumer behavior to Thai fruit consumption during COVID-19 pandemic in Jakarta, Indonesia. Journal of Socioeconomics and Development, 4(2), 166-179. https://doi.org/10.31328/jsed.v4i2.2367

Смерічевський, С. Ф., Smerichevskyi, S. F., Князєва, T. B., Kniazieva, T. V., \& Walid, A. (2018). Assessment of marketing activity management in territorial units: Theoretical-methodological approach. https://doi.org/10.30525/22560742/2018-4-4-326-333 